\title{
Primary Failure of Tooth Eruption Associated with Secondarily Inflamed Dental Follicle: Inflammatory Follicular Cyst?
}

\author{
Gustavo de Almeida Camargo LAUTENSCHLÄGER \\ Marcelo Contador GALLINA \\ Osny FERREIRA JÚNIOR \\ Vanessa Soares LARA
}

Department of Stomatology, School of Dentistry of Bauru, University of São Paulo, Bauru, SP, Brazil

\begin{abstract}
Primary failure of eruption represents a cessation of tooth eruption before emergence not due to a physical barrier or abnormal position and has no systemic cause. This failure of tooth eruption is rare phenomenon and it has not been associated with alterations of dental follicle. This case report describes a permanent right first molar with primary failure of eruption at the inferior border of the mandible presenting microscopic, clinical and radiographic findings compatible with follicular cystic lesion. The follicular tissues of this molar showed microscopic aspects of inflammation. Thus, pericoronal tissues surrounding long-term unerupted teeth with primary failure of eruption has potential to develop into odontogenic cysts. The lesion presented herein probably arose in association with a periodontal pocket mesial to the adjacent second molar, representing an atypical inflammatory follicular cyst. This case shares etiological, radiological and microscopic features with the usual form of the inflammatory follicular cyst associated with infected primary teeth, except for the infection pathways reaching the tooth follicle. The controversies regarding the terminology for this cyst are discussed.
\end{abstract}

Key Words: inflammatory follicular cyst, eruption primary failure, odontogenic cysts.

\section{INTRODUCTION}

Tooth eruption has been defined as the movement of a tooth from its site of development within the alveolar process towards its functional position in the oral cavity. The dental follicle is necessary for the coordinated resorption and deposition of bone on opposing sides of the erupting tooth during the intraosseous movement (1). Genetic and environmental factors are included in the multifactorial nature of tooth eruption, which may be disturbed at any stage of development (2).

The eruption failure may result from a variety of causes, including mechanical interference and failure of the eruptive process $(3,4)$. Primary failure of eruption is defined as a cessation of tooth eruption before emer- gence that is not due to a physical barrier in the eruption path, does not result from an abnormal position, and has no systemic cause $(2,5,6)$. Posterior teeth are more commonly affected by primary failure of eruption, and the involved tooth may have initiated its eruption into occlusion before submerging. Involvement may be unilateral or bilateral, and compromised primary or permanent teeth have been reported. Although other members of the family may be affected, they are not usually close relatives (5).

As observed with retained third molars, it appears that unerupted teeth left in place represent the risk of developing into tumors or cysts such as dentigerous cyst and odontogenic keratocyst (7). A review of the literature suggests that primary failure of tooth eruption is rare and it has not been reported associated with an

Correspondence: Prof. Dr. Osny Ferreira Júnior, Departamento de Estomatologia (Cirurgia), Faculdade de Odontologia de Bauru, USP, Al. Octávio Pinheiro Brisolla, 9-75, Vila Universitária, 17012-901 Bauru, SP, Brasil. Tel: +55-14-32358258. Fax: +55-14-32234679. e-mail: osnyfjr@fob.usp.br 
alteration of dental follicle. This report describes a permanent right first molar with primary failure of eruption at the inferior border of the mandible presenting microscopic, clinical and radiographic findings compatible with follicular cystic lesion. The terminology of the cyst that might be more adequate for this case, in also discussed.

\section{CASE REPORT}

A 44-year-old woman came to the clinic of the Department of Stomatology at Bauru Dental School, University of São Paulo, with pain and swelling of the gingivae.

According to the patient, the swelling had gradually developed over a period of 2 months. Intraoral examination revealed a firm and small swelling of the gingivae on the buccal aspect of the mandibular right second molar. Periodontal probing caused pus to drain from the mesial sulcular area of this tooth and it was established that probable pockets measuring 6-7 $\mathrm{mm}$ in depth had formed. Although the distal root presented deep caries in its cervical third, thermal pulp testing showed that the tooth was vital.

The radiograph confirmed the presence of all erupted permanent teeth, except for the mandibular right first molar. There was a negative family history of

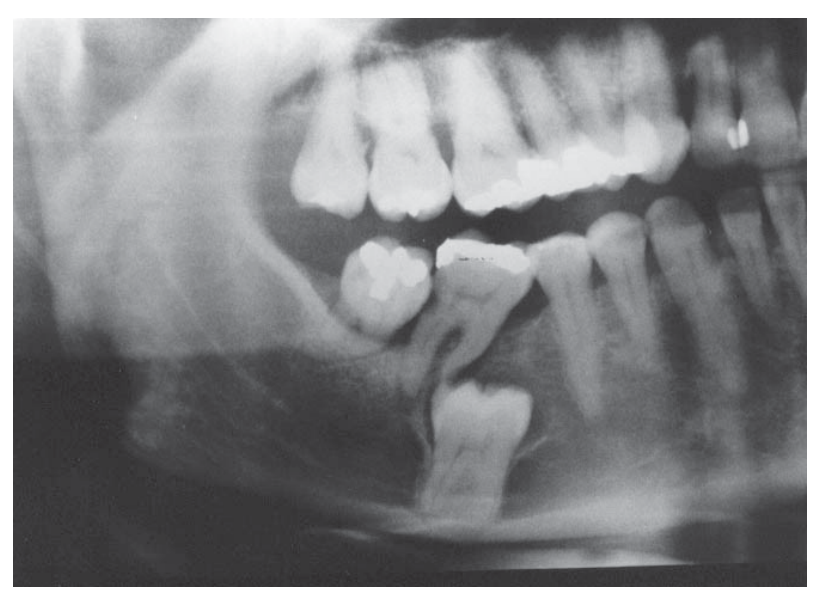

Figure 1. Panoramic radiograph showing radiolucency in the furcation area of the mandibular right second molar and a communication from the periodontal pocket on mesial side of mandibular right second molar to the follicular space associated with the crown of the unerupted adjacent first molar. dental anomalies or craniofacial, dermal or skeletal dysmorphologies. The mesial displacement of the adjacent mandibular right second molar was evident. Based on root development of this tooth and the absence of any other signs, the diagnosis suggested strongly to be a primary failure of eruption of the mandibular right first molar. In addition, radiographic examination revealed radiolucency in the furcation area of the mandibular right second molar forming a communication from the periodontal pocket on its mesial side to the follicular space associated with the crown of the mandibular right first molar. There was also loss of the lamina dura surrounding the roots of the mandibular right second molar (Fig. 1). The intraoral radiograph showed an approximately $3 \mathrm{~mm}$ radiolucency around the crown of the first molar confirming the presence of an increase of the dental follicle (Fig. 2).

The treatment consisted on the removal of the dental follicle and curettage of the lesion with extraction of the mandibular right first molar via surgical exposure by buccal aspect of the bone.

During the surgery, a fluid-filled cavity lined predominantly by thin, soft tissue was observed. Histological examination revealed a central cavity lined with thick cuboidal epithelium resembling reduced enamel epithelium and non-keratinized stratified squamous epithelium. The connective tissue wall was quite heavily

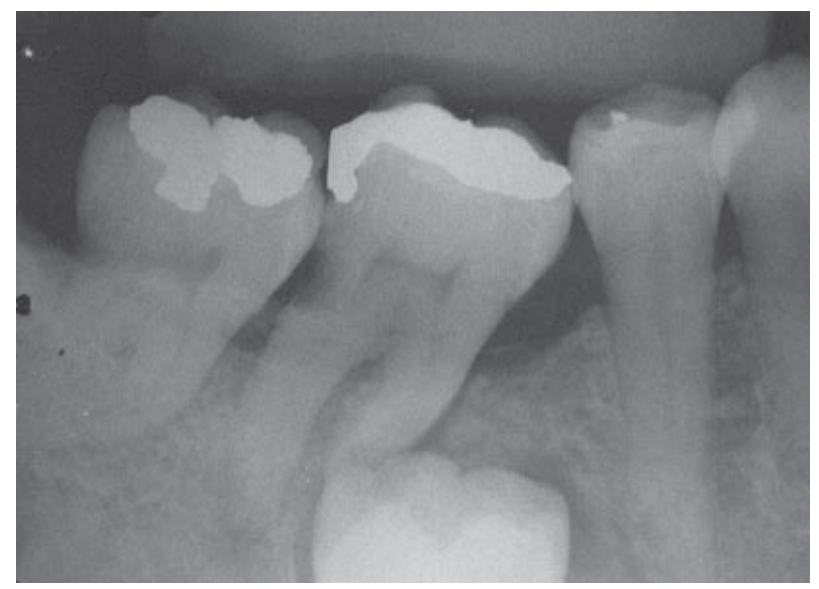

Figure 2. Periapical radiograph showing about $3 \mathrm{~mm}$ radiolucency around the crown of the first molar and a close-up view of the communication from the periodontal pocket on the second molar to the follicular space of the unerupted first molar. Note loss of the lamina dura surrounding the roots of the right second molar. 
infiltrated by chronic inflammatory cells (Fig. 3). The patient was examined 17 months later, and no sign of swelling or inflammation at the side of the lesion was observed. Radiographic examination showed that the radiolucency was no longer visible and that new bone had formed around the roots of the affected tooth with partial reconstitution of lamina dura (Fig. 4). The patient was referred for endodontic and orthodontic treatment with aim being alignment of the posterior teeth for further prosthetic evaluation. The patient gave informed consent for report of this case.

\section{DISCUSSION}

In terms of involved tissues, odontogenic cysts can be designated as follicular cysts, such as dentigerous cysts, which enclose the crown of an unerupted tooth by expansion of its follicle and are attached to the neck of the tooth. On the basis of their pathogenesis, a dentigerous cyst is a developmental odontogenic cyst (8). However, Benn and Altini (9) proposed the existence of dentigerous cysts, inflammatory in nature, that occur as a result of an inflammation from a nonvital predecessor primary tooth or other source spreading to involve the tooth follicle. If inflammation progresses into the follicular tissues, various degenerative or destructive changes in the follicle may follow, usually resulting in proliferation of the reduced enamel epithelium (10). The inflammatory exudate may cause separation of reduced enamel

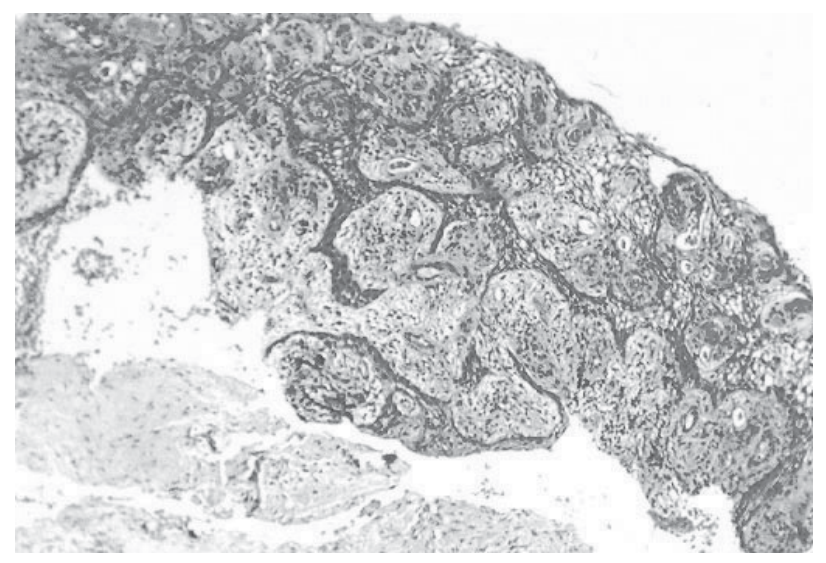

Figure 3. Photomicrograph showing a cystic lining composed of non-keratinized stratified squamous epithelium and a connective tissue wall heavily infiltrated by chronic inflammatory cells (Original magnification $\cong x 12.5 ; \mathrm{HE}$ ). epithelium from the enamel with resultant cyst formation (9). In 1970, Main had already described an "inflammatory coronal cyst" that developed around the partly formed crown of a second premolar probably as a result of intrafollicular spread of periapical inflammation from a recently extracted primary tooth (11). Ten years later Shaw et al. (10) reported 13 cases of follicular cysts involving premolars that apparently were associated with infected primary predecessors. As these cases showed microscopic findings of chronic inflammation, the authors suggested the term inflammatory follicular cyst, which was shared by Main (12).

Considering the suggested nomenclature and the possibility of other inflammatory pathways reaching the tooth follicle and not only from adjacent infected primary teeth (9), the follicular cyst in the present paper might be more appropriately described as inflammatory follicular cyst rather than dentigerous cyst, occurring in a tooth with primary eruptive failure. This case shares etiological, radiological and microscopic features with the usual form of the inflammatory follicular cyst associated with infected primary teeth $(9,10,13)$, except that the infection originated from a communication of the periodontal pocket of adjacent tooth. Intrafollicular spread of inflammation from associated primary teeth had already been very characterized (9-13). On the other hand, neither different inflammatory pathway reaching the tooth follicle nor secondary infections of

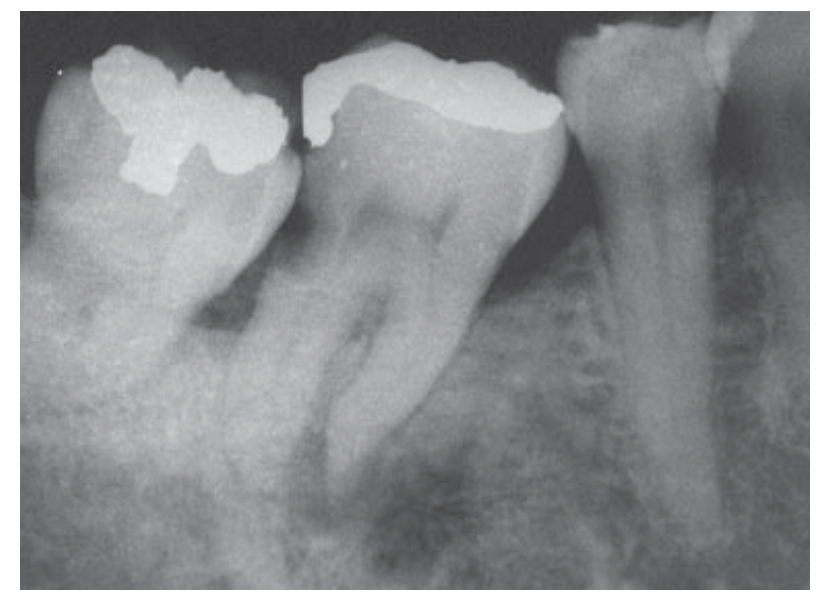

Figure 4. Periapical radiograph taken 1 year and 5 months after the intervention showing new bone formation around the roots of the affected tooth. 
dental follicle in teeth with primary failure of eruption have been reported. Thus, this case seems to represent an unusual or atypical inflammatory follicular cyst, and may indicate that the pericoronal tissue of an unerupted tooth, as a result of eruption failure, has the potential to develop pathology due to infection, which could subject the patient to health risks if untreated. Moreover, similarly to impacted third molars, odontogenic tissues surrounding long-term unerupted teeth has the potential to develop into a wide variety of cysts and tumors (14-16).

\section{RESUMO}

A falha primária de erupção é caracterizada pelo não irrompimento de um dente sem que haja impedimento mecânico ou que o dente esteja em posição anormal ou devido à causas sistêmicas. É um fenômeno raro e não foi associado com alterações do folículo dentário. Este relato descreve um caso de falha primária de erupção de um primeiro molar inferior direito permanente, localizado na base da mandíbula, que apresenta achados clínicos, radiográficos e microscópicos compatíveis com cisto folicular. O folículo pericoronário deste molar apresentou aspectos microscópicos de inflamação. Assim como os tecidos pericoronários dos dentes não irrompidos, a longo prazo, os folículos pericoronários dos dentes com falha primária de irrompimento têm o potencial para desenvolver cistos odontogênicos. Esta lesão provavelmente surgiu em associação com uma bolsa periodontal na mesial do segundo molar adjacente, caracterizando um cisto folicular inflamatório atípico. Este caso apresenta características etiológicas, radiográficas e microscópicas comuns nos cistos foliculares inflamatórios associados a dentes decíduos infectados, com exceção das infecções que alcançam o folículo. São discutidas ainda as controvérsias relativas à terminologia deste cisto.

\section{REFERENCES}

1. O'Connell AC, Torske KR. Primary failure of tooth eruption: a unique case. Oral Surg Oral Med Oral Pathol Oral Radiol Endod 1999;87:714-720.
2. Pytlik W. Primary failure of eruption: a case report. Int Dent J 1991;41:274-278.

3. Dibiase AT, Leggat TG. Primary failure of eruption in the permanent dentition of siblings. Int $\mathrm{J}$ Paediatr Dent 2000;10:153-157.

4. Noffke CE, Chabikuli NJ, Nzima N. Impaired tooth eruption: a review. SADJ 2005;60:422,424-5.

5. Proffit WR, Vig KWL. Primary failure of eruption: a possible cause of posterior open-bite. Am J Orthod 1981;80:173-190.

6. Suri L, Gagari E, Vastardis H. Delayed tooth eruption: pathogenesis, diagnosis, and treatment. A literature review. Am J Orthod Dentofacial Orthop 2004;126:432-445.

7. Girod SC, Gerlach KL, Krueger G. Cysts associated with longstanding impacted third molars. Int J Oral Maxillofac Surg 1993;22:110-112.

8. Kramer IRH, Pindborg JJ, Shear M. World Health Organization-International Histological Classification of tumors: Histological typing of odontogenic tumors. 2nd ed. Berlin: Springer-Verlag; 1992.

9. Benn A, Altini M. Dentigerous cysts of inflammatory origin. Oral Surg Oral Med Oral Pathol Oral Radiol Endod 1996;81:203-209.

10. Shaw W, Smith M, Hill F. Inflammatory follicular cysts. J Dent Child 1980;47:97-101.

11. Main DMG. Epithelial jaw cysts: a clinicopathological reappraisal. Brit J Oral Surg 1970;8:114-125.

12. Main DMG. Epithelial jaw cysts: 10 years of the WHO classification. J Oral Pathol 1985;14:1-7.

13. Silva TA, Sá ACD, Zardo M, Consolaro A, Lara VS. Inflammatory follicular cyst associated with an endodontically treated primary molar: a case report. ASDC J Dent Child 2002;69:271-274,234.

14. Curran AE, Damm DD, Drummond JF. Pathologically significant pericoronal lesions in adults: Histopathologic evaluation. J Oral Maxillofac Surg 2002;60:613-617.

15. Baykull T, Saglan AA, Aydin U, Basak K. Incidence of cystic changes in radiographically normal impacted lower third molar follicles. Oral Surg Oral Med Oral Pathol Oral Radiol Endod 2005;99:542-545.

16.Nigam S, Gupta SK, Chaturvedi KU. Adenomatoid odontogenic tumor - a rare cause of jaw swelling. Braz Dent J 2005;16:251-253.

Accepted August 29, 2006 